\title{
LEGAL EUROPEANIZATION OUTSIDE THE EUROPEAN UNION
}

\author{
Peter-Christian Müller-Graff \\ Ruprecht-Karls-Universität Heidelberg, Juristische Fakultät
}

\begin{abstract}
Legal Europeanization outside the European Union is an epochal multifaceted phenomenon. The text distinguishes three types: the autonomous Europeanization, the preparatory Europeanization and the contracted Europeanization. All three types are illustrated by prominent examples. The article discusses differences and commonalities between them in regard to their substantive scope of subject matters covered, their reasons and their public and societal ramifications as well as the perspectives of this development.
\end{abstract}

Keywords: Europeanization, European Union

\section{INTRODUCTION}

Legal Europeanization outside the European Union is an epochal multi-faceted phenomenon and a great topic. Until now it is not adequately explored. Despite a multitude of publications on the legal europeanization of individual third states or groups of third states (e.g.: O. Blažo; P. Forstmoser; H. P. Graves; N. A. Guney; H.-H. Herrnfeld; Chr. Hillion; V. Kunová; M. Maresceau; P.-CHr. Muller-Graff; R. Petrov; J. Piskulinski; N. Šišková; L. Tichý; D. Tzouganatos; L. Vékás; J. Zemánek; F. Zoll) the phenomenon still deserves a comprehensive comparative investigation of its types, its substantive scope and its reasons. This contribution can only serve as a rather short outline. Legal Europeanization can be understood, in its core, as any adaptation of the law of non-EU member States to legal rules and principles of the European Union. An early example was the adoption of the Greek competition Act of 1977, ${ }^{1}$ which entered into force three years before Greece became a member of the European Economic Community (EEC). It shaped the Greek competition law in accordance with the substantive provisions of the cartel law of the EEC, ${ }^{2}$ in particular with the prohibitions of cartel agreements and abuses of a dominant market position as contained in (today) Articles 101 and 102 TFEU $^{3}$ and created the challenging tasks of establishing an adequate national infrastructure for the interpretation and application of this imported set of rules and its judicial review. ${ }^{4}$ Since then this phenomenon of non-EU-members which adapt their legal order to the law of the European Union has increasingly occurred. The following observations focus on four of its aspects: on its typology, on its substantive scope, on its reasons, on its public and societal ramifications and on its perspectives.

The submitted understanding of legal Europeanization draws a distinguishing line in relation to the regularly expected phenomenon of compliance of undertakings from abroad with EU law.

1 Gesetz 703/1977; PAPADELLI A.: Beweislastverteilung bei der privaten Durchsetzung des Kartellrechts. Münster: LIT Verlag, 2010, p. 248ff.

2 PAPATHOMA-BAETGE, A.: Die Neuregelung des Kartellrechts in Griechenland, in: Recht der internationalen Wirtschaft, 1996, p. 1013.

3 PAPADELLI, A.: Beweislastverteilung bei der privaten Durchsetzung des Kartellrechts, p. 249.

4 See as an analysis of the transplantation of foreign antitrust devices TZOUGANATOS, D.: Zur Rezeption fremden Rechtsguts im Bereich des Wirtschaftsrechts: dargestellt am Beispiel der Problematik einer Fusionskontrolle nach dem griechischen Kartellgesetz. Bonn: Stollfuss, 1983. 
Complying with the legal standards is a normal worldwide requirement for any undertaking which pursues economic activities within a specific jurisdiction. E.g., should the result of the British referendum of June 23, 2016 lead to the withdrawal of Britain from the European Union, then the enterprises located in Britain which aim at dealing within the internal market of the Union would nevertheless have to comply with the applicable European regulatory law. This would imply for banks located in Britain to open a registered office in a Member State of the Union in order to obtain a "European passport" for rendering services to customers within the internal market.

\section{THE TYPES OF LEGAL EUROPEANIZATION OUTSIDE THE EUROPEAN UNION}

For the purpose of systematizing the types of legal Europeanization outside the European Union I propose to differentiate between three basic forms: the autonomous Europeanization, the preparatory Europeanization and the contractual Europeanization.

\subsection{Autonomous Legal Europeanization}

The autonomous legal Europeanization can be described as Europeanization without any obligation towards the Union or any current desire for membership in the Union. This is the situation of Switzerland as far as the Swiss adaptation to secondary Union law is concerned. It is true that Switzerland has concluded a multitude of bilateral agreements with the European Union. They range from the Free Trade Agreement (1972) to the Agreement on the Free Movement of Persons (1999). However, these agreements do not provide, in principle, for the permanent adaptation of the Swiss legal order to new acts of the legislation of the Union, ${ }^{5}$ in particular to directives which aim at harmonizing national laws in order to facilitate the free movement of goods or services. This secondary law deals with market-relevant standards of, e.g., health protection, consumer protection, environmental protection. Since non-compliance of Swiss goods or services with the protection standards of secondary Union law would bar their marketing within the internal market (as far as the bilateral agreements do not yet address these issues), Switzerland has developed a technique which is called "autonomer Nachvollzug" " (autonomous adaptation to relevant secondary Union law). This technique is marked by the tendency to revise national Swiss law in order to facilitate exports of enterprises which are located in Switzerland into the internal market. As a matter of course Switzerland, being a non-member of the European Union, can have no right to partake in the decision on adopting secondary Union law. In the future this might well become the situation of Britain after its withdrawal from the Union, if it desires to facilitate exports of enterprises which are located in Britain into the internal market. It would be an ironic punchline of Boris Johnson's selling point of Brexit as Britain's "independence day"'

5 See for the Agreement on the Free Movement of Persons GROSSEN, D. W. - COULON, C. de: Bilaterales Abkommen über die Freizügigkeit zwischen der Schweiz und der Europäischen Gemeinschaft und ihren Mitgliedstaaten. In: THÜRER, D. - WEBER, R. H. - PORTMANN, W. - KELLERHALS, A. (Hrsg.): Bilaterale Verträge I und II Schweiz EU. Zürich: Schulthess, 2007, p.135, 139.

6 See FORSTMOSER, P.: Der autonome Nach-, Mit- und Vorvollzug europäischen Rechts: das Beispiel der Anlagefondsgesetzgebung. In: Festschrift für Roger Zäch. Zürich: Schulthess, 1999, p. 523ff.

7 See http://www.theguardian.com/politics/2016/jun/22/brexit-independence-day-claim-nonsense-says-david-cameron (22.6.2016). 


\subsection{Preparatory Legal Europeanization}

A second type of legal Europeanization can be identified as preparatory Europeanization. Similar to the autonomous Europeanization it occurs without any obligation towards the European Union and is in this respect autonomous. However, at the same time this type of legal Europeanization is motivated and driven by the endeavour of the respective state to prepare itself for future membership in the European Union.

The epochal historical examples were the adaptations of the national legal orders of East Central European States to the legal order of the European Union on their path to accession to the Union in the nineties of last century. ${ }^{8}$ While it is true that the so called Europe Agreements between the EC and its Member States on the one side and the respective East Central European State on the other side addressed the issue of approximation of laws, they did not contain a precise obligation in this respect. E.g., Article 68 of the respective Agreement with Poland read: "The Contracting Parties recognize that the major precondition for Poland's economic integration into the Community is the approximation of that country's existing and future legislation to that of the Community. Poland shall use its best endeavours to ensure that future legislation is compatible with Community legislation". Article 60 of that Agreement designated as substantive areas in particular "customs law, company law, banking law, company accounts and taxes, intellectual property, protection of workers at the working place, financial services, rules on competition, protection of health and life of humans, animals and plants, consumer protection, indirect taxation, technical rules and standards, transport and the environment". In short, this provision comprised the whole scope of the internal market law. However, this wording did not impose obligations on the respective East Central European State to implement secondary Community law. Also this situation did not change after the Copenhagen summit in 1993 when the European Communities and its Member States paved the way for a potential enlargement. ${ }^{9}$ It is well known that the main part of Community legislation was gradually implemented by the candidate states before accession on May $1^{\text {st }}, 2004$ in an epochal "road-mapped"-process which developed in connection with and parallel to the accession negotiations on the 31 so called chapters of subject matters. ${ }^{10}$

This pattern of preparatory legal Europeanization is, in principle, also provided for in the Stabilisation and Association Agreements between the Union and its Member States with the Balcans. Article 72 par. 1 of the Agreement with Serbia, which can serve as an example, is nearly identically worded to the Europe Agreement with Poland: "The Parties recognize the importance of the approximation of the existing legislation on Serbia to that of the Community and of its effective legislation. Serbia shall endeavour to ensure that its existing laws and future legislation will be gradually made compatible with the Community acquis." However, different from the former Agreement with Poland, the Agreement with Serbia already leaps into a procedural form of obliging Serbia to approximate its law, since the quoted provision contains three further paragraphs concerning the road to be

8 See ANDERSON, M. - GAUTRON, J. C. - ESTRIN, S. - HESSE, J. J. - MORAN, M. - MÜLLER-GRAFF, P. Ch.: The Legal, Economic and Administrative Adaptations of Central European Countries to the European Community. BadenBaden: Nomos, 1992; MÜLLER-GRAFF, P.-Ch. (ed.): East Central European States and the European Communities: Legal Adaptation to the Market Economy. Baden-Baden: Nomos, 1993; MÜLLER-GRAFF, P.-Ch. (ed.): East Central Europe and the European Union: From Europe Agreements to a Member Status. Baden-Baden: Nomos, 1997.

9 Bulletin EC 6/1993, I 13; MÜLLER-GRAFF, P.-Ch. (ed.): East Central Europe and the European Union: From Europe Agreements to a Member Status, p. 9, 17.

10 See HEUSEL, W. (Hrsg.): Die Osterweiterung der Europäischen Union. Köln, 2002, p. 21, 27. 
taken: namely the starting date of the approximation (viz the signing of the Agreement), the target date of the implementation of all elements of the Community acquis referred to in the Agreement (viz the end of the transitional period) and the sequence of the steps of approximation (viz fundamental elements of the internal market acquis, the matters of justice, freedom and security as well as other trade-related areas ranking as first priority). In addition, Article 72 of the Agreement with Serbia provides for the implementation of Union law on the basis of a programme to be agreed upon between the Union and Serbia and for the definition of detailed arrangements for the monitoring of the implementation of the approximation of legislation and for law enforcement actions which have to be taken. In other words, a certain "road-mapping" is already included in this Agreement.

\subsection{Contractual Legal Europeanization}

A third type of legal Europeanization can be described as contractual Europeanization. This form occurs in all agreements of the Union with third states in which the Union succeeds in inserting standards of Union law into them, although it has to be kept in mind that an agreement on rules is not identical with the actual implementation of them. The Union has been very successful in extending the contracted radius of its own legal standards in many geographic directions by means of international treaties (see infra.). Several reasons contribute to this achievement. A first element can be seen in the consequence of the internal principle of conferral (Art. 5 par. 2 TEU) which limits the Union in its competences and tasks and hence guides it to primarily focus on enhanced commercial agreements. These are partially inspired by topics of its internal market standards and the experience of their ramifications into all market-relevant areas of legal issues such as the protection of health, consumers, workers and the environment. This reason is, secondly, connected to the obligation of the Union as laid down in Article 21 TEU that its action on the international scene "shall be guided by the principles which have inspired its own creation, development and enlargement", among them the rule of law, and which it should seek "to advance in the wider world." A third reason for the Union's successful emphasis on furthering its legal standards in international treaties can be seen in its deeply rooted self-understanding of its basic character as "Rechtsgemeinschaft", as the first President of the EEC, Walter Hallstein, named it ${ }^{11}$ - a Community of law mirrored by the establishment and the task of the European Court of Justice to ensure that in the interpretation and application of the Treaties the law is observed (Article 19 TEU) and accentuated by the "rule of law" as one of the values on which the European Union is founded (Article 2 TEU). Last, but not least, the presumably most important reason for the radiation of Union law is due to the attractiveness of the Union and, in particular, its internal market (with all its consequences for the legal order). The results of this development are many international agreements which attempt to "export" principles and even rules of primary and secondary Union law. This applies, e.g., to the already mentioned Agreements with Switzerland and the Balcans and also to the Ankara Agreement with Turkey, ${ }^{12}$ the EEA-Agreement with Norway, Iceland and Liechtenstein ${ }^{13}$ and the Association Agreements with now independent,

11 HALLSTEIN, W.: Die Europäische Gemeinschaft. 5.Aufl. Düsseldorf, Wien: Econ Verlag, 1979, p. 51ff.

12 GÜNEY, N. A.: Abkommen Europäische Union - Türkei. In: HATJE, A. - MÜLLER-GRAFF, P.-Ch. (Hrsg.): Europäisches Organisations- und Verfassungsrecht (Enzyklopädie Europarecht Band 1). Baden-Baden: Nomos, 2014, § 23 (p. $1029 f f)$.

13 GRAVER, H. P.: Der Europäische Wirtschaftsraum. In: HATJE, A. - MÜLLER-GRAFF, P.-Ch. (Hrsg.): Europäisches Organisations- und Verfassungsrecht (Enzyklopädie Europarecht Band 1), \$19 (S. 921 ff.); MÜLLER-GRAFF, P.-Ch. SELVIG, E. (Hrsg.): The European Economic Area - Norway's Basic Status in the Legal Construction of Europe. Berlin: Verlag Arno Spitz, 1997. 
former Soviet Republics such as Ukraine, ${ }^{14}$ Moldovia $^{15}$ or Georgia. ${ }^{16}$ They all mirror more or less some of the topics of the Union's internal market law and include subject matters connected to it. Traces of this approach can even be found in Agreements of the Union with Canada ${ }^{17}$ Mexico $^{18}$ Central American states, ${ }^{19}$ South American states (Chile, ${ }^{20}$ Colombia and Peru ${ }^{21}$ ) and East Asian States (Singapur, ${ }^{22}$ Vietnam $^{23}$ ).

By far the closest and most intensive legal Europeanization in this respect is the European Economic Area (EEA-Agreement) which contains the four basic freedoms and the competition rules of the Treaty on the Functioning of the European Union (TFEU) in nearly identical terms ${ }^{24}$ and provides for a functioning system of ensuring as uniform an interpretation as possible of this Agreement. ${ }^{25}$ In addition, it provides for a simple mechanism to incorporate into EEA-law any new secondary law which is relevant for establishing homogenous rules in the common economic area. ${ }^{26}$ A remarkable range of the topics of secondary law of the Union is part of the new generation of the (voluminous) Association Agreements with East European states such as the Ukraine. The meanwhile suspended negotiations of a TTIP ignited an intensive public debate whether it would be harmful to the Union if the contractual Europeanization could not be pursued. All in all it seems that the Union can offer a much deeper legal experience than any other actor on the globe for a conceptually coherent legally governed, functioning transnational commercial exchange. ${ }^{27}$

\section{THE SUBSTANTIVE SCOPE OF SUBJECT MATTERS OF LEGAL EUROPEANIZATION OUTSIDE THE EUROPEAN UNION}

The substantive scope of legal Europeanization can not be neatly linked to the outlined different types of this epochal development. However, a cautious assessment can be attempted. As already analyzed, all types have in common that their topics mirror the center of gravity of the Union's main

14 ABl. 2014 L 161/3.

15 ABl. 1998 L 181/1.

16 ABl. 2014 L 261/4

17 See: European Commission - Press Release 30 October 2016 (EU-Canada summit: newly signed trade agreement sets high standards for global trade); $\operatorname{COM}(2016) 444$ final.

18 See Free Trade Agreement EU-Mexico 1997/1999.

19 See: EU startet Freihandel mit Zentralamerika, http://www.handelsblatt.com (19.5.2010).

20 See: EUR-Lex: EC-Chile Association Agreement (22.3.2005); OJ 2002 L 352.

21 See: Trade Agreement between the EU and its Member States, of the one part, and Colombia and Peru, of the other part, OJ 2012 L 354.

22 See: EU-Singapore Free Trade Agreement, http://trade.ec.europa.eu (29.6.2015).

23 See: EU-Vietnam Free Trade Agreement, http://trade.ec.europa.eu (1.2.2016).

24 See Articles 8 et seq. And 28 et seq. EEA-Agreement.

25 See Article 106 EEA-Agreement.

26 See Article 98, 102 EEA-Agreement. Article 102 EEA-Agreement provides: „In order to guarantee the legal security and the homogeneity of the EEA, the EEA Joint Committee shall take a decision concerning the amendment of an Annex to this Agreement as closely as possible to the adoption by the Community of the corresponding new Community legislation with a view to permitting a simultaneous application of the latter as well as of the amendments of the Annexes to the Agreement".

27 See for a comparison of German, European and US-American approaches to the rule of law in the relation of state and market MÜLLER-GRAFF, P.-Ch. - JACKSON, J. H. (eds.): Transatlantic Perspectives on International Economic Law. Baden-Baden: Nomos, 2009, p. $79 f f$. 
objectives, as laid down in Article $3 \mathrm{TEU},{ }^{28}$ and its competences and its law. In short, they reflect elements of its transnational market law with all its ramifications into other areas of law which are relevant for the functioning of a market with free and undistorted competition and guard mandatory public interests. On this common ground slight differences in the substantive scope of legal Europeanization may be identified when comparing the three types described above.

The autonomous Europeanization pursued by Switzerland - and in the future probably by Britain - will usually comprise detailed rules in order to facilitate exports of enterprises located in its territory into the internal market. The preparatory Europeanization will comprise also the adaptation to general principles in the sense of the values of the Union as contained in Article 2 TEU. This is demonstrated by the (already contractually Europeanizing) texts of the Stabilisation and Association Agreements with the Balcans. E.g., Article 2 of the Agreement with Serbia contains the proclamation, that "Respect for democratic principles and human rights as proclaimed in the Universal Declaration of Human Rights and as defined in the Convention for the Protection of Human Rights and Fundamental Freedoms ... and the rule of law as well as the principles of market economy ... shall form the basis of the domestic and external policies of the Parties and constitute essential elements of this Agreement." This wording resembles Articles 2 and 21 TEU. In the cases of contractual Europeanization the relation between detailed rules and principles varies. While the EEA-Agreement and the bilateral Agreements with Switzerland are businesslike orientated to a plentitude of detailed rules which grant the access to the internal market, the Agreement with the Ukraine which draws its extensive volume from the bulk of detailed rules also contains a starting article on general principles equivalent to the respective article in the Agreement with Serbia.

\section{REASONS FOR THE LECAL EUROPEANIZATION OUTSIDE THE EUROPEAN UNION}

From the aforesaid it can easily be deduced that the reasons for legal Europeanization outside the European Union differ according to its types.

The autonomous Europeanization is obviously rooted in the interest of the respective states to facilitate the access of undertakings located in their territory to successfully manoeuvre within the legal order of the internal market. As a consequence of the Europeanization of the market relevant rules in their home country they are getting trained in and accustomed to internal market law standards, as exemplified in the case of Switzerland.

Different from the reason of autonomous Europeanization, the basic motivation for the preparatory Europeanization, while also comprising this aspect, reaches further than alleviating the business of enterprises, since the adaptation of the domestic legal order to Union law serves as a precursor for the intended full membership with all its components, e.g. in the areas of internal security and crime prevention, as seen in the case of the Balcans. Here, on the other side, also the interests of the Union promote this approximation in the rather soft way of conditionalities for support programs as seen during the course to the Eastern enlargement of the Union. This allowed also the support for the costly adaptation to the high environmental law standards of the Union (also in order to avoid

28 See for Art. 3 TEU MÜLLER-GRAFF, P-Ch.: Verfassungsziele der Europäischen Union. In: DAUSES, M. (Hrsg.): Handbuch des EU-Wirtschaftsrechts. München: C. H. Beck, 2012, A I. 
distorted competition). Even and in particular if a future membership in the Union is politically not yet decided upon from its side, the Union is bound by Article 8 TEU to develop a special relationship with neighbouring countries, founded on the values of the Union and, according to Article 21 TEU, guided by the principles which have inspired its own creation, development and enlargement. This leads to a central conclusion. Taking into account that the Union is based on law and hence is, in its genetic code, a "Rechtsgemeinschaft" 29 and, in particular, pursues all its activities on the basis of transnational commercial and market relations and corresponding transnational law, its approach to external relations is inherently driven to offer its internal legal standards to its neighbours.

Eventually the reasons for contractual legal Europeanization are marked by the same set of normative guidelines on the side of the Union, while the reasons of the third country depend upon its specific motivation for closer relation with the Union as exemplified in the case of the three EFTA members in their EEA-relation with the Union and its member states.

\section{PUBLIC AND SOCIETAL RAMIFICATIONS OF THE LECAL EUROPEANIZATION OUTSIDE THE EUROPEAN UNION}

The political and societal ramifications of legal Europeanization outside the European Union affect, above all, the legal system of the third country on all of its public and societal levels. The legislation is challenged to adapt the statutory order to the respective principles and rules of European Union law. The administration is challenged to apply the implemented new rules in the sense which the national legislator has given them. The judiciary is challenged to interpret them. The societies of third countries encounter in their Europeanized domestic legal order concrete pieces of the consequences of the normative point of orientation of the European Union as laid down in Article 2 TEU, namely, in the words of this provision, of a polity based on the values of respect for human dignity, freedom, democracy, equality, the rule of law and respect for human rights, and of a society in which pluralism, non-discrimination, tolerance, justice, solidarity and equality between women and men prevail.

The EEA-Agreement, which most closely resembles Union law for the common economic area based on homogenous rules, even provides for the objective of the Contracting Parties to arrive at as uniform an interpretation as possible of the provisions of this Agreement and those provisions of Union legislation which are substantially reproduced in the Agreement. ${ }^{30}$ To these ends the EEA Joint Committee is charged to act so as to preserve the homogenous interpretation of the Agreement and to realise, in full deference to the independence of courts, a system of exchange of information concerning judgments by the EFTA Court, the European Court of Justice (ECJ) and the Courts of last instance of the EFTA states. ${ }^{31}$ In fact, both the ECJ and the EFTA Court observe the respective jurisprudence of the other court. ${ }^{32}$ In the absence of a mechanism as in the EEA national law may expressly or implicitly, even in the form of an assumption, oblige the domestic administration and judiciary to interpret the respective amended domestic law in conformity with the interpretation of parallel provisions or principles of Union law.

29 See above.

30 See Article 105 EEA-Agreement.

31 See Article 106 EEA-Agreement.

32 See, e.g., BAUDENBACHER, C.: The EFTA Court and the European Court. In: MÜLLER-GRAFF, P.-Ch. - SELVIG, E. (Hrsg.): EU-EEA Relations. Berlin: Berlin Verlag, 1999, p. 65ff. 
The mutual observation of the respective jurisprudence can even impact on the jurisprudence in Union law. The incumbent President of the EFTA Court, Carl Baudenbacher, has listed several cases in which the ECJ followed the EFTA Court in the interpretation of EEA-law. ${ }^{33}$ This can also influence the interpretation of parallel provisions in Union law. In this way, legal Europeanization outside the Union can conversely impact on the development of Union law, if the latter draws inspiration from its export.

\section{SUMMARY: PERSPECTIVES OF LEGAL EUROPEANIZATION OUTSIDE THE EUROPEAN UNION}

The perspectives of this epochal process of legal Europeanization depend upon the attractiveness, the radiation and the aura of the European Union and its transnational legal order and, in particular, its internal market law with all its ramifications in the traditional areas of law. As long as a third country will perceive the Union as an appealing polity and society, the Europeanization of its domestic legal order will progress to the degree considered beneficial for its own aspirations. This again should motivate the Union to assume responsibility for developing its legal order in the most convincing way possible.

\section{Bibliography:}

ANDERSON, M. - GAUTRON, J. C. - ESTRIN, S. - HESSE, J. J. - MORAN, M. - MÜLLER-GRAFF, P. Ch.:The Legal, Economic and Administrative Adaptations of Central European Countries to the European Community. Baden-Baden: Nomos, 1992.

BAUDENBACHER, C.: The EFTA Court and the European Court. In: MÜLLER-GRAFF, P.-Ch. - SELVIG, E. (Hrsg.): EU-EEA Relations. Berlin: Berlin Verlag, 1999.

FORSTMOSER, P.: Der autonome Nach-, Mit- und Vorvollzug europäischen Rechts: das Beispiel der Anlagefondsgesetzgebung. In: Festschrift für Roger Zäch. Zürich: Schulthess, 1999.

GROSSEN, D. W. - COULON, C. de: Bilaterales Abkommen über die Freizügigkeit zwischen der Schweiz und der Europäischen Gemeinschaft und ihren Mitgliedstaaten. In: THÜRER, D. - WEBER, R. H. - PORTMANN, W. KELLERHALS, A. (Hrsg.): Bilaterale Verträge I und II Schweiz - EU. Zürich: Schulthess, 2007.

GRAVER, H. P.: Der Europäische Wirtschaftsraum. In: HATJE, A. - MÜLLER-GRAFF, P.-Ch. (Hrsg.): Europäisches Organisations- und Verfassungsrecht (Enzyklopädie Europarecht Band 1). Baden-Baden: Nomos, 2014.

GÜNEY, N. A.: Abkommen Europäische Union - Türkei. In: HATJE, A. - MÜLLER-GRAFF, P.-Ch. (Hrsg.): Europäisches Organisations- und Verfassungsrecht (Enzyklopädie Europarecht Band 1). Baden-Baden: Nomos, 2014.

HALLSTEIN, W.: Die Europäische Gemeinschaft. 5.Aufl. Düsseldorf, Wien: Econ Verlag, 1979.

HEUSEL, W. (Hrsg.): Die Osterweiterung der Europäischen Union. Köln, 2002.

MÜLLER-GRAFF, P.-Ch. (ed.): East Central European States and the European Communities: Legal Adaptation to the Market Economy. Baden-Baden: Nomos, 1993.

MÜLLER-GRAFF, P.-Ch. (ed.): East Central Europe and the European Union: From Europe Agreements to a Member Status. Baden-Baden: Nomos, 1997.

33 See above. 
MÜLLER-GRAFF, P-Ch.: Verfassungsziele der Europäischen Union. In: DAUSES, M. (Hrsg.): Handbuch des EUWirtschaftsrechts. München: C.H.Beck, 2012.

MÜLLER-GRAFF, P.-Ch. - JACKSON, J. H. (eds.): Transatlantic Perspectives on International Economic Law. BadenBaden: Nomos, 2009.

MÜLLER-GRAFF, P.-Ch. - SELVIG, E. (Hrsg.): The European Economic Area - Norway's Basic Status in the Legal Construction of Europe. Berlin: Verlag Arno Spitz, 1997.

PAPADELLI A.: Beweislastverteilung bei der privaten Durchsetzung des Kartellrechts. Münster: LIT Verlag, 2010.

PAPATHOMA-BAETGE, A.: Die Neuregelung des Kartellrechts in Griechenland, in: Recht der internationalen Wirtschaft, 1996, p. 1013.

TZOUGANATOS, D.: Zur Rezeption fremden Rechtsguts im Bereich des Wirtschaftsrechts: dargestellt am Beispiel der Problematik einer Fusionskontrolle nach dem griechischen Kartellgesetz. Bonn: Stollfuss, 1983.

\section{Contact information:}

Professor Dr.iur.habil.Dr.h.c.mult.Peter-Christian Müller-Graff, Ph.D.h.c., MAE p.mueller-graff@igw.uni-heidelberg.de

Ruprecht-Karls-Universität Heidelberg

Friedrich-Ebert-Platz 2

D-69117 Heidelberg

Germany 